\title{
Heterologous expression and purification of Leptospira spp recombinant proteins to leptospirosis vaccine development
}

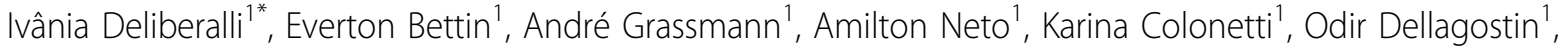 \\ Everton Silva ${ }^{2}$
}

From 5th Congress of the Brazilian Biotechnology Society (SBBIOTEC)

Florianópolis, Brazil. 10-14 November 2013

\section{Background}

Leptospirosis is an infectious disease of humans and other mammals and an important public health problem worldwide, mainly in developing countries. The disease is among the most common zoonosis worldwide and is caused by infection with pathogenic spirochetes of the genus Leptospira. [1]. Rodents and others wild or domestic animals are asymptomatic hosts that can carry Leptospira spp in the kidneys and shed high number of them in urine. The infection usually occurs through direct contact with reservoirs contaminated urine [1]. Leptospires have a double membrane structure, where the LPS are the main constituting antigen in its outer membrane. Those proteins are potential targets to development of vaccines due to its capability of being recognized by the hosts immune system [2-4]. There is no vaccine evaluable worldwide to protect humans against leptospirosis. In the last decades a number of studies evaluated recombinant proteins as vaccine antigens, with limited or no success. We randomly chose three conserved lipoproteins to evaluate as recombinant proteins: those expressed by lic10260, lic10365 and lic11360 ORFs in the L. interrogans L1-130 genome. Lipoproteins are associated with membranes and may be exposed in the cell surface, allowing recognition by immune responses. In this study we cloned, expressed and purified these proteins.

\section{Methods}

Primers were designed to add restriction enzyme sites to each gene that were amplified from Leptospira borgpetersenii sorovar Ballum strain $4 \mathrm{E}$ genomic DNA. The sequences

${ }^{1}$ Laboratório de Vacinologia - Centro de Desenvolvimento Tecnológico

Unidade de Biotecnologia - UFPel, Pelotas, Brazil

Full list of author information is available at the end of the article were cloned into $E$. coli $\mathrm{pAE}$ expression vector. The recombinant vectors were utilized to express recombinant Leptospira proteins in E. coli BL21 (DE3) Star cells. The cultures were grown to log phase and the recombinant proteins expression induced by adding IPTG. The cells were harvested, lysed and the proteins were purified in denaturing conditions using $\mathrm{Ni}^{2+}$ affinity chromatography. Purified proteins were analyzed by SDS-PAGE and Western Blot with anti-6xHis antibody. The final concentration of each protein was determined using the commercial kit BCA Protein Assay.

\section{Results and conclusions}

The cloning was successful and resulted in the pAE/ lic10260, pAE/lic10365 and pAE/lic11360 recombinant vectors. The proteins were expressed in E. coli BL21 (DE3) Star and purified, yielding high amount each with satisfactory purity. The WB with anti-6xHis antibody marked recombinant proteins in the expected size: $12 \mathrm{kDa}$ for rLIC10260; $37 \mathrm{kDa}$ for rLIC10365 e $24 \mathrm{kDa}$ for rLIC11360. These proteins are now target antigens to develop a recombinant vaccine against leptospirosis. Currently we are evaluating these proteins in an established hamster model of leptospirosis using homologous and heterologous challenges.

\footnotetext{
Authors' details

${ }^{1}$ Laboratório de Vacinologia - Centro de Desenvolvimento Tecnológico Unidade de Biotecnologia - UFPel, Pelotas, Brazil. ${ }^{2}$ Grupo de Pesquisas em Doenças Transmitidas por Animais - Faculdade de Veterinária - UFPel, Pelotas, Brazil.
}

Published: 1 October 2014 


\section{References}

1. Adler B, de la Pena Moctezuma A: Leptospira and leptospirosis. Veterinary Microbiology 2010, 140(3-4):287-296.

2. Dellagostin OA, Grassmann AA, Hartwig DD, Félix SR, da Silva ÉF, McBride AJ: Recombinant vaccines against Leptospirosis. Human Vaccines 2011, 7(11).

3. Haake DA, Matsunaga J: Leptospira: A spirochaete with a hybrid outer membrane. Molecular Microbiology 2010, 77(4):805-814.

4. Silva EF, Medeiros MA, McBride AJ, Matsunaga J, Esteves GS, Ramos JR, Santos CS, Croda J, Homma A, Dellagostin OA, Haake DA, Reis M, Ko Al: The terminal portion of leptospiral immunoglobulin-like protein LigA confers protective immunity against lethal infection in the hamster model of leptospirosis. Vaccine 2007, 25(33):6277-6286.

doi:10.1186/1753-6561-8-S4-P141

Cite this article as: Deliberalli et al: Heterologous expression and purification of Leptospira spp recombinant proteins to leptospirosis vaccine development. BMC Proceedings 2014 8(Suppl 4):P141.

\section{Submit your next manuscript to BioMed Central} and take full advantage of:

- Convenient online submission

- Thorough peer review

- No space constraints or color figure charges

- Immediate publication on acceptance

- Inclusion in PubMed, CAS, Scopus and Google Scholar

- Research which is freely available for redistribution

Submit your manuscript at www.biomedcentral.com/submit 